\title{
Social Aspects of Urban Forestry URBAN GREENING AND SOCIAL BENEFITS: A STUDY OF EMPOWERMENT OUTCOMES
}

\section{by Lynne M. Westphal}

\begin{abstract}
This paper provides a framework in which to consider social benefits of urban and community forestry projects. The framework clarifies who gets the benefits-An individual? An organization? A community? Further, the benefits can be derived from passive and/or active experience of the urban forest. Examples of social benefits in each category are reviewed. The paper also presents findings from a research project that investigated practitioner claims for social benefits of urban greening projects. Practitioner assessments of the benefits received modest support in the research findings, but their assessments were not entirely accurate, leading to some true and some false claims of social benefits. Empowerment theory structured the investigation and analysis and provided insight for implementation of projects that aim for providing social benefits. The concepts of empowering versus empowered people were particularly helpful. Specifically, the empowering nature of each site's project organizer, the openness of the project process, and the overall organizing history of the block were important to achieving empowerment outcomes. The paper concludes with recommendations for practitioners interested in fostering empowerment through urban and community forestry projects.
\end{abstract}

Key Words. Social benefits; empowerment; community; volunteers.

Many urban and community foresters report dramatic social impacts from greening cities and towns. More trees, landscaped lots and streets, roofs, and parks not only improve the appearance and the environmental quality of an area, they can sometimes have an impact on critical social issues such as health care, education, crime and safety, economic development, and social disenfranchisement. Understanding how urban and community forestry can address these issues is not simple because trees are often seen as amenities_-something everyone likes but no one really needs-and because the psychological and social mechanisms that make trees effective in addressing these issues are subtle and not fully understood. Still, urban and community forestry projects are increasingly implemented with social benefits as goals of the project.

This paper serves several purposes. First, it presents a framework for social benefits from urban forestry that will be useful for practitioners as they craft urban greening programs that aim for these benefits (practitioners includes professionals involved in program delivery for urban and community forestry, whether they are in government, nonprofit organizations, or volunteers). Second, the paper provides a brief review of the research regarding social benefits of improved urban forests in cities and towns. Finally, the paper presents results from a research project investigating the empowerment outcomes of urban greening projects in Chicago, Illinois, U.S. (Westphal 1999). Many urban and community forestry practitioners use the word "empowerment" when describing the social benefits they see coming from urban and community forestry and other urban greening projects. Understanding what empowerment is, then, helps us to understand the potential for these benefits. The framework, review of existing research literature, and information from the research study may help urban and community foresters get the most out of their projects, including strengthening the social fabric of their communities.

\section{SOCIAL BENEFITS FRAMEWORK}

Increased understanding of the potential social benefits from urban and community forestry has led to more programs designed with these benefits as intended outcomes (Pauline 1993; Phillips and Garcia 1994). Greater clarity about the different types of benefits can increase the likelihood of achieving these outcomes. A simple framework helps to clarify the issues. First, to whom do the benefits accrue? An individual person? An organization (a block club, business group, or some other group)? The community as a whole? Second, the benefits discussed in the literature stem either from passive experiences of a green environment (e.g., a view from a hospital window) or from active involvement in greening the environment (e.g., organizing skills developed from a tree planting project). Table 1 presents these two categories with examples of the potential benefits in each. In following sections, the categories are discussed in more detail.

\section{Who Gets the Benefits?}

Benefits can accrue to an individual, an organization, or an entire community. Greater understanding of whether problems and their potential solutions are at the individual, organizational, or community level can help hone the urban 
Table 1. Potential benefits from urban greening.

\begin{tabular}{lll}
\hline & $\begin{array}{l}\text { Passive experience of a } \\
\text { green environment }\end{array}$ & $\begin{array}{l}\text { Active involvement in } \\
\text { greening the environment }\end{array}$ \\
\hline Individual & $\begin{array}{l}\text { Shorter hospital stay, } \\
\text { improved cognitive function }\end{array}$ & $\begin{array}{l}\text { Sense of accomplishment, } \\
\text { food security }\end{array}$ \\
Organization & Stronger business districts & $\begin{array}{l}\text { More members, } \\
\text { stronger ties to politicians }\end{array}$ \\
Community & Reduced crime & More external resources \\
\hline
\end{tabular}

Empowerment is a word often used to describe the social benefits of tree planting programs, and it is often labeled a community benefit. However, viewed from a public goods perspective, empowerment often is not a community benefit but an individual or organizational one. The new-found power, or new-found exercising of existing power, is developed by a person or group but may not accrue to someone who stayed home and didn't and community forester's approach. This isn't always easyproblems are usually multifaceted, and benefits that first affect one level can have a ripple effect to other levels.

Take, for example, the Forest Service response to the social unrest in Los Angeles after the 1992 Rodney King police brutality trial. Lack of parks, recreation, and open space has been a chronic concern in Los Angeles, reported as a factor in the Watts unrest of the 1960s (U.S. Kerner Commission 1968) as well as the Rodney King unrest of the 1990s. The Forest Service contributed to rebuilding Los Angeles with a greening and jobs program (USDA Forest Service, no date). Making greening an effective response to social issues requires understanding the subtleties of these problems (in the case of the recent Los Angeles unrest, long-term effects of racism). There are issues at all three levels in this example: individuals facing chronic unemployment and discrimination, organizations struggling with inadequate resources to meet serious local needs, communities beleaguered by years of disinvestment. The Forest Service program directly addressed the individual level by providing short-term jobs and the organizational level by providing resources for local nonprofit groups. If there were community-level impacts, they would have been indirect, resulting from a greener, more cared-for environment and other evidence of investment in the community.

What is truly a community benefit is the most problematic of the three levels. Colloquially, "community" often means something warm, fuzzy, and a little nostalgic. Practitioners often describe any positive social benefit as a "community benefit." In looking at the impacts of trees and tree planting, it is important to be more precise. Community benefits are those that accrue to people whether or not they were involved in a program or project. In this way, community benefits are public goods, a fundamental concept in economics. A public good is nonexclusive and nonrival in consumption (Amacher and Ulbrich 1986). Public television is a good example of a public good. You can watch the programming whether or not you contribute to your local station (nonexclusive) and no matter how many others watch, too (nonrival in consumption). Therefore, job creation is not a direct community benefit; neither is fostering organizational capacity. These are benefits at the individual and organizational levels. participate. But changes for one person or group can have a ripple effect. The newly empowered block club might then take action to create a safer block, a benefit enjoyed by that stay-at-home person. This would be a true community benefit. Alternately, a newly empowered individual might take control of a new tree planting project to such an extent that there could be negative ramifications for the block. Individual benefits can add up, or multiply, to create organizational- or community-level benefits. Community benefits might help specific individuals. But clarity about who gets which benefits is important, particularly when designing or gathering support for a program. Promising community benefits when individual benefits are more likely could have negative repercussions for a program. Developing a project aimed at providing individual benefits when organizational benefits are needed could also backfire.

\section{Passive Experience of a Green Environment}

There are numerous benefits available to individuals, organizations, and communities from a green environment. Views of green space can have dramatic impacts on people: improved worker productivity (Kaplan 1993b), reduced domestic violence (Kuo and Sullivan 1996), shorter healing times (Ulrich 1984).

Most documented benefits of living, working, or playing in a green environment accrue to individuals. Views of vegetation and water (e.g., rivers or lakes) have been shown to reduce stress, improve healing, and reduce driving frustration and aggression (Ulrich 1984; Parsons et al. 1998; Cackowski 1999). Views of green space from home are also linked to a greater sense of well-being and neighborhood satisfaction (Fried 1982; Kaplan 2001).

Living and playing in green places can be very important to children. Play in places with trees and vegetation can support children's development of skills and cognitive abilities (Taylor et al. 1998) and lessen the symptoms of Attention Deficit and Hyperactivity Disorder (ADHD) (Taylor et al. 2001). Living in a green environment can improve school performance (Wells 2000) and reduce reported incidents of domestic violence (Kuo 2003).

Some benefits of green space that accrue to individuals have clear benefits to organizations as well. Workers report 
greater productivity when they have a view of green space from their place of work, and their supervisors also feel that these workers are more productive (Kaplan 1993a). Business districts with trees are considered more desirable and are thought to have more desirable goods and services (Wolf 2003). These benefits can accrue to a local chamber of commerce and to a municipality.

An example of a benefit of green space at the community level is that greener space can increase perceptions of safety. In a public housing setting, Kuo et al. found that residents reported that they would feel a greater sense of safety in their development if it had well-maintained landscaping including trees and grass (1998). In another study, these researchers found that greener public housing neighborhoods also tend to be safer, with fewer incivilities and reported crimes (Kuo and Sullivan 2001).

\section{Active Involvement in Greening the Environment}

Benefits from active involvement with urban and community forestry stem from tree planting and landscaping projects, volunteer tree maintenance, and the organizing that goes into successful projects. Some of these benefits derive from the fact that gardens and tree planting projects are relatively simple and easy when compared, for example, to fighting discriminatory lending practices or to large-scale job creation. This "do-ability" can provide a modest victory or small win which, in turn, sometimes leads to an individual or group taking on more difficult projects (Weick 1984; Feldman and Stall 1994). Benefits that individuals or groups seek can vary from food production to strengthening intergenerational ties to beautification to reducing crime (Bouza 1989; Patel 1992; Pauline 1993; Westphal 1993; McDonough et al. 1994; Westphal 1995).

At the individual level, planting a tree or vegetable garden can provide a sense of accomplishment and/or effectiveness that might otherwise be lacking in a person's day-to-day lifeeffectiveness at helping the environment or their neighborhood (Westphal 1993; McDonough et al. 1994). This sense of accomplishment and effectiveness is a component of a modest victory. A garden can also provide food security, a tangible benefit to an individual (Patel 1992).

At the organization level, the benefits of active involvement with urban and community forestry can include more members in a block club or other organization and stronger ties to politicians or agencies. Both of these benefits can then foster greater effectiveness for the organization in meeting its goals. These project goals might be oriented towards the neighborhood, the environment, or both (Westphal 1993; McDonough et al. 1994).

At the community level, the organization's contacts with agencies and politicians can lead to more external resources. These resources, in turn, can lead to public-goodtype benefits. For instance, if by successfully completing a tree planting project, a neighborhood gets to know their councilperson better, and through the councilperson increases their contact with the police, the neighborhood might become safer. This increased safety would be a community benefit.

\section{Empowerment: A Cautionary Tale}

Many practitioners have noticed significant change in neighborhoods and communities from participation in urban greening projects (Kollin 1986; Lyons 1986; Bouza 1989; Evans 1994). These stories are often compelling, even dramatic. Practitioners often use empowerment language to describe these changes, but few studies have investigated these outcomes. This research was designed to fill this gap, investigating practitioner claims of social benefits—such as empowerment-from urban greening projects.

Empowerment is problematic. It is a widely used word, with almost as many meanings as people using it. Even in academia, there are many disciplines that approach the idea of empowerment from different angles. I used empowerment theory as developed in Community Psychology to frame this research (Rappaport 1987; Zimmerman et al. 1992; Perkins and Zimmerman 1995; Zimmerman 2000). In Community Psychology, empowerment grew from a recognized need to change the paternalistic outlook on the part of service providers in various fields. This has meant a change from illness- or needs-based interventions where the practitioner is the expert aiding patients, to an approach of collaboration where an individual's or group's strengths are recognized and developed (Rappaport 1981; Zimmerman and Warschausky 1998). The research and theoretical development of community psychology's empowerment theory to date have been strongest at the individual level.

While definitions of empowerment vary, they all have at their root the ability for an individual, organization, or community to effect positive change. Empowerment indicators will vary because the nature of these changes will be different for different situations. Still, there are some common themes to empowerment indicators, including increased mastery and control, increased skills, access to resources, and ties within and outside community.

Zimmerman articulated an important refinement of empowerment theory-the differentiation between empowered and empowering (Zimmerman 1995, 2000). When people are empowered, they, themselves, show mastery of skills, control over aspects of their environment, and an ability to make changes that lead to a higher quality of life for themselves (and sometimes others). When people empowering, they are able to foster empowerment in others, facilitating changes in another individual or group to make changes in their circumstances. An individual might be empowered, or become empowered, but not be empowering. Likewise, another person or organization might be empowering but 
not particularly empowered. It is possible to be both empowered and empowering, but it is not a given.

\section{METHODS}

To investigate the empowerment outcomes from urban greening, I conducted a qualitative research project using photoelicitation and semistructured interview techniques (Chenoweth 1984; Collier and Collier 1986; Dey 1993; Lofland and Lofland 1995; Westphal 1999). Photoelicitation is a research technique that uses photographs as a part of the datagathering process. Both the photos and the interviews about the photos are data analyzed by the scientist. Individuals from four residential blocks in Chicago, where residents were involved in the City's Greencorps Chicago program, were interviewed. Greencorps is a technical assistance program for Chicagoans interested in landscaping projects in their neighborhood. Each of the blocks went through the program in 1995. I interviewed in 1997, 1-1/2 to 2 years after the landscape project was completed. The intervening time allowed the impact of the project to stabilize, to neither be too rosy from recent success nor too dim from recent troubles.

I discussed each 1995 project with Greencorps staff and then selected two projects for which the staff thought there were social benefits from the project and two for which the staff thought there were not. The blocks were as similar as possible in socioeconomic terms; all were low- to moderateincome African American neighborhoods. One block was mixed Hispanic/African American; another was a low-rise public housing development (Table 2 summarizes respondent characteristics). I presented the study as being about neighborhood change not gardens or urban forestry. After initial contact with the project organizer on the block, I recruited respondents for the study by door-to-door canvassing. Each block's sample included both participants and nonparticipants of the greening project.
I gave each respondent a single-use camera and asked him or her to take ten pictures of things he or she thought had changed for the better or worse on the block over the past 5 years. Respondents took photos of many kinds of changes, from abandoned or burned-out houses, to gang members, to the garden project. Each block had a core set of changes that a majority of respondents photographed. In the interviews, respondents were asked about the photos they took and why they took them, going in depth about the garden and one other change they photographed (Table 3). If a respondent didn't take a photo of the garden, after discussing the photos he or she did take, I showed a picture of the garden and explained that others on the block had photographed it and asked the respondent's opinion of the project. If residents were interested in participating in the study but weren't able to take or interested in taking their own photos, I interviewed them using photos taken by other block residents. The photos selected for this set were representative of the changes a majority of block respondents photographed and were taken by several different respondents. In this way, as many people on each block as possible were interviewed, including project participants and nonparticipants, and the garden was included in each interview.

The interview and analysis were structured by empowerment theory as discussed above. Indicators of empowerment included efficacy, mastery, control, new resources, participation, increased skills, proactive behavior, critical awareness, sense of competence, shared leadership, meeting organizational goals, key brokers in decision making, extended influence, connections to other community groups, and responding to threats to quality of life. Some examples from the data are useful to illustrate how the empowerment indicators might look in response to interview questions. Efficacy might be indicated at the individual level by a comment such as "It made me feel that we had a

Table 2. Respondent characteristics.

\begin{tabular}{|c|c|c|c|c|}
\hline & \multicolumn{2}{|c|}{ Greencorps perceived as success sites } & \multicolumn{2}{|c|}{ Greencorps perceived as failure sites } \\
\hline & Halsted & Ashland & Pulaski & Jefferson Homes \\
\hline Racial/ethnic composition & Black $^{z}$ & Black & Mixed & Black \\
\hline Number of interviews & 12 & 10 & 11 & 24 \\
\hline Gender & 7 women, 5 men & 7 women, 3 men & 11 women, 0 men $^{y}$ & 23 women, 1 man \\
\hline Average age of respondent & 47 & 41 & 34 & 46 \\
\hline Average number of children & 3.1 & 2.4 & 1.8 & 3.7 \\
\hline Average household size & 3.2 & 3.4 & 4.2 & 3.1 \\
\hline Average length of residency (years) & 17 & 15.4 & 13.4 & 18 \\
\hline$\%$ homeowners & $67 \%$ & $60 \%$ & $64 \%$ & $0 \%$ \\
\hline $\begin{array}{l}\text { Education (\% with education } \\
\text { or training past high school) }\end{array}$ & $50 \%$ & $70 \%$ & $82 \%$ & $54 \%$ \\
\hline Work status (\% employed) & $66 \%$ & $80 \%$ & $100 \%$ & $42 \%$ \\
\hline \multirow[t]{2}{*}{ Income } & $58 \%<25,000$ & $33 \%<15,000$ & $44 \%<25,000$ & $100 \%<25,000$ \\
\hline & $25 \%<15,000$ & $44 \%>40,000$ & $18 \%<15,000$ & $54 \%<15,000$ \\
\hline
\end{tabular}

${ }^{2}$ I use the term "Black" rather than "African American" because that is what my respondents said they preferred

yI had two informal interviews with men on the block; neither took or responded to photographs. 
Table 3. Photographs taken by respondents by site.

\begin{tabular}{|c|c|c|c|c|}
\hline & \multicolumn{2}{|c|}{ Greencorps perceived as success sites } & \multicolumn{2}{|c|}{ Greencorps perceived as failure sites } \\
\hline & Halsted & Ashland & Pulaski & Jefferson Homes \\
\hline Number of interviews & 12 & 10 & 11 & 24 \\
\hline $\begin{array}{l}\text { Average number pictures taken } \\
\text { (respondents were asked to take 10) }\end{array}$ & & & & \\
\hline $\begin{array}{l}\text { (respondents were asked to take } 10) \\
\% \text { respondents that photographed the garden }\end{array}$ & 18 & $\begin{array}{l}15 \\
44 \%\end{array}$ & 7 & $\begin{array}{l}15 \\
0 \%\end{array}$ \\
\hline $\begin{array}{l}\text { \% respondents that photographed the garden } \\
\text { Pictures of other greening projects? }\end{array}$ & no & some & no & over half \\
\hline
\end{tabular}

chance, a better chance of improving the community" and at the organizational level by

Oh, that is beautiful, I mean, there was once upon a time, when there ... nothin' but weeds all the way through there. We come over, the guys got together, and we just cut it, and cut it all down till the next Saturday the peoples come in, and landscape the way they did and kept it up. It was beautiful. It was the first change on the block that the block club start.

The indicator "responding to threats to quality of life" might be reflected in a comment such as

It uh, it kinda makes you feel, when you first turn this corner, makes you feel kinda comfortable. "All right, this is a nice neighborhood." Makes you feel more at least, well I see all the guys out here, but somebody really cared about the block to have something that looks nice.

I used QSR's N4 qualitative analysis software to facilitate the coding and analysis of the text data (Qualitative Solutions and Research 1997). QSR's N4 and other qualitative analysis software do not conduct the analysis for the scientist; rather, the software supports the process of searching for trends and indicators, pursuing emerging concepts in the data, and conducting quality-control checks (Dey 1993; Miles and Huberman 1994; Lofland and Lofland 1995; Westphal 2000). I analyzed the transcribed interviews for evidence and counterevidence of the empowerment indicators described above (Westphal 1999).

\section{RESULTS: GREENING PROJECT PERCEIVED AS "SUCCESS" SITES}

Recall that the four study sites were chosen to reflect the greening practitioners' assessment of sites where there had been positive social changes because of the project ("success" sites) and those where there had not been positive social changes because of the project ("failure" sites). The two sites where greening project staff thought there had been social benefits from the urban greening project were Halsted and Ashland (site names are pseudonyms-each is named for a major thoroughfare near each project block; respondent names are also pseudonyms). Did these blocks show signs of social benefits? Could these benefits be associated with the greening project?

\section{Halsted-“Bring the Block Up"}

This block showed the most signs of empowerment and related benefits of the four blocks. In reaction to increased antisocial activity ("devilment") and an increasing number of abandoned buildings, residents wanted to "bring the block up." After signing petitions that successfully blocked a tavern from reopening on the block, the reinvigorated block club decided to put in a garden on a vacant lot. The block club held meetings that were well attended; recruited block members to help out, delegating tasks based on residents' skills; and installed the garden. Since installation, the residents have done a good job at maintaining the project and adding to it. Many houses up and down the block had gardens in the front yard and exhibited other signs of care. The alderman was impressed with the efforts of this block and changed the boundaries of a tax increment financing district to include this block, hoping inclusion would bring additional benefits to the block. In the words of the alderman's chief of staff, "if they can do it, anyone can do it"- "it" being improving their block. The garden project gave some residents increased feelings of control. In the words of Mr. Nichols, a man in his 60 s who participated in the greening project,

... because like you say you get a sense of feeling if somebody is over there doing something that they aren't suppose to be doing you have a right to tell them not to do it. Why? Because we did this for this particular thing to get it like it is and now we want to keep it like that, you know. So that, it give you the authority to run somebody out of there or talk to 'em about getting out of there if they are doing something against, against the grain. If I had did nothing, nothing, but hadn't participated then I wouldn't have had that type of feeling....

The project was not without controversy, however. The vacant lot had been used by men on the block for car repair and hanging out and by young children for play. Since the garden was constructed, the gate has been locked. It is a low gate, but some block club members patrol the lot and keep the children from playing and the men from hanging out there. Younger men on the block resent the loss of use of the lot and feel blamed for any piece of litter that appears on the lot. They also feel that the children have lost an important play space. This situation has created some ill will on the block. 
The block club wanted to continue to improve the block but were unsure what to do next. If they had learned of another program, they probably would have joined. However, they were not aware of other programs and were not sure how to seek them out. Their progress from resisting the tavern to organizing and maintaining the garden was stymied by this lack of future direction.

The strength on this block was the decision-making process and project implementation. The many open meetings fostered participation. There wasn't total agreement on what to do, but decisions were not made behind closed doors. There were empowerment benefits at the individual and organizational levels, with some evidence of potential community level empowerment.

\section{Ashland-Dream Site?}

The greening program staff thought the project on Ashland was a dream site; they thought there was lots of local involvement and lots of local impact. One of the many empty lots was cleaned up and no longer used for drinking and drugs. It was planted with shrubs, flowers, and a few trees. The organizer, Martha, placed a religious statue in the middle of the garden, and many plants had religious significance (e.g., burning bush). Other nearby residents saw the project and signed up for the Greencorps program to do greening projects on their blocks. In general, the block showed a high degree of organization: block parties and clean-ups were regular events, neighbors mowed each other's lawns, and a small planter box stood on one corner.

What the greening program staff didn't see was that most of the people involved in this project were part of Martha's extended family, and many of them moved off the block shortly after the project was done. The garden was just behind Martha's house, on a lot where a house had recently been razed, and control of the lot was part of a feud between her and a neighbor. Martha's daughter describes it this way:

... the man that use to live there, he was having problems with the lady next door. She didn't like him either ... Now if she [the neighbor] would have took over [the lot], it would have been [a horrible mistake] I believe that she wanted that property. ... It so happen that ... Martha knew Kristin [from an environmental nonprofit], and Kristin knew something about Greencorps, and they was having money funding for the garden, if it was a block program. So we looked into it and that's what we did. When they tore down the building we went to the next garden class and then we got it started. ... [We had permission] from the owner and everything and he said you all can use it indefinitely, "as long as she don't have it, I'll be happy" [laughs].

Martha got extra funds to put up a 6-foot high chain-link fence. Other block residents wanted a shorter fence, one that wasn't as formidable. Martha and her daughter had the only keys to the lock on the gate. Most residents of the block saw it as Martha and her daughter's garden, not something for the block. They felt that maintenance was her task and wondered why the garden wasn't kept weeded. Block residents appreciated Martha's determination and her knowledge about who to call to solve problems, but didn't feel that the garden was theirs or had a huge impact on the block. With some neighbors, the garden caused resentment.

The decision-making process and project implementation on Ashland looked open and participatory but was in fact run by one determined woman. What Martha wanted was what happened. The garden was behind her house, "not on this block" to most block residents, and the project caused some hard feelings. The greening program staff didn't readily see these aspects of the project's story. The empowerment outcomes were, if anything, negative: Martha was acting on existing skills, so there was no individual empowerment gain. At the organizational level, the project made continued progress in addressing local issues more difficult for residents. The one glimmer of community-level empowerment was in the other block groups that joined Greencorps based on what they saw of Martha's garden.

\section{RESULTS: GREEN PROJECTS PERCEIVED AS "FAILURE" SITES}

The two sites where Greencorps practitioners thought that there had not been any positive social change because of the greening projects were Pulaski and Halsted (again, these site and respondent names are pseudonyms). Did these two blocks in fact have no positive changes associated with the greening project? If so, why was this? If not, why did the greening program staff miss the positive changes?

\section{Pulaski-Local Dictators}

The greening program staff saw the project on Pulaski as an utter failure. The organizers, twin sisters Jill and Jane, lived on an adjacent block and decided to turn an empty lot on Pulaski into a garden. This decision was announced at a local beat meeting (meetings organized by the local police and leaders to address local problems). Residents were asked to sign up to help with the project. Block residents at the beat meeting said they wanted a play lot, but Jill and Jane said "no." A block resident said,

Oh, everybody was saying it should be a playground. But then they [Jill and Jane] said "no," that if we make it a play ground, then it invites gangs for them to sell drugs over there.... They were either going to make it a play lot or a - that [referring derisively to the garden lot]....

A couple of people on the block did help with the garden, but most of the volunteers came from neighboring blocks. The block residents who did participate had negative stories 
to tell about Jill and Jane's pushiness. After the flowers and shrubs were planted, many were taken overnight and showed up in neighbors' yards up and down the block. This happened several times as the organizers replanted the garden. No one maintained the lot, and weeds and grass grew high, obscuring the few remaining flowers and shrubs. Jill and Jane put a fence across the back of the lot that limited access from the alley. Some block residents saw this as a positive outcome of the project.

The residents on the block were uncomfortable with the decline of the block. Fear was palpable on this block, more so than in the other locations. Several residents reported that even their block parties were full of squabbles and conflict.

The decision-making and project implementation process on Pulaski was dictatorial, but Jill and Jane didn't see themselves that way. They felt that their hard work to improve the neighborhood was unappreciated and the block residents should maintain the site. They were proud of their efforts to bring resources to the block and wanted the neighborhood to garner more attention from the city and regional nonprofit groups.

Jill: $\quad$... we thought it would bring people out to work on it, remember, and "oh, well, you got something interesting going on here-let's all work on it." Nobody's done anything for it. Everybody wants you to do everything for 'em.

Jane: Well, the other thing was the thing that we thought that we were gonna do, put the garden here, is like, what's going to end up happening today on [a neighboring street with a large garden]. The mayor's gonna come out, rejuvenate the block, that they've worked on with the ... old police commander that was transferred.

Jill: And the whole community.

Jane: And the whole community. Everybody get together and neighbors start, neighbors helpin' neighbors, ...

But working together on problems was not something the residents of Pulaski were ready to do. They had retreated inside their houses, and the garden project did not pull them out or pull them together. Jill and Jane might have enhanced their individual empowerment, but for residents on the project block there was no increase in empowerment at the individual level—and potentially negative repercussions at the organizational and community levels.

\section{Jefferson Homes-Long History of Organizing}

Jefferson Homes is a low-rise public housing development, described by residents as "the cream of the crop" of Chicago Housing Authority (CHA) developments. With an active core group of organizers, residents of Jefferson Homes maintain numerous projects including a laundromat (proceeds support scholarships), a convenience food store, and children's activities. Based on these successes and CHA's continued disinvestment in their community, the core organizers were working toward resident management of their development. It is in this context that the Greencorps project was initiated. But because the residents did not follow through with the project, the Greencorps staff felt it was a failure and that this failure reflected the residents' inability to organize and carry through on a project.

Mrs. Thompson, a deeply respected resident leader, had planned a vegetable garden on vacant land across a busy street from the development. Residents had a vegetable garden on the site in the past, and Mrs. Thompson and others wanted to resurrect it. Residents also had two communal vegetable plots within the development, and many had gardens in their own yards. Mrs. Thompson decided to sign up for Greencorps, counting on resident support for the project if they were accepted into Greencorps and the plant materials arrived.

Jefferson Homes was accepted in Greencorps and the plants did come, but they arrived late, in the middle of a major heat wave (there were over 700 heat-related deaths during this heat wave). It was already late in the season to plant vegetables, and because of the heat wave, it was unsafe for people to be out doing heavy work. The residents tried to keep the plants shaded and watered, but the ground was too dry to successfully plant the garden.

There were several greening projects that did take place in the development that year, organized by members of the core group. New sod was installed around the perimeter, and numerous circular flowerbeds were planted throughout the development. At the same time, the resident management process consumed most of the core group of active residents. There was a lot going on, in the words of one resident peripherally involved in the projects:

Well, sometime you have the same people working on the same, you know they can only do so much work. They can only be in so many places, you know. Once that started I don't think they really could get anybody to finish it up.... You know we have a lot of other things going on. We've been having a lot things going on in the last two or three years. Like we had this resident management that's coming up ...

In some ways, the organizers were good at building on other residents' strengths, but Mrs. Thompson felt that she couldn't ask others to do work that she was not a part of: 
"... Then I got busy, too, I wouldn't put it all on that. Because if you get somebody to work with you, you have to be out there with them." In this way, the amount of work that could be done was limited by what a few lead organizers could actively be involved in.

While the core group of organizers accomplished many things, some projects were left undone, including the Greencorps garden, a victim of bad weather. The greening projects that were implemented drew on existing skills. New individual-, organizational-, and community-level empowerment for these residents was coming from the soon-to-berealized resident management of their development.

\section{IMPLICATIONS FOR EMPOWERMENT}

Empowerment outcomes from urban and community forestry projects are possible but far from a given. Practitioners don't always see the full story on a block. What look like successes may be failures, and failures may be viewed as successes. Practitioners may not see the full impact, good or bad-Ashland and Jefferson Homes are both examples of this. Greening projects may be most empowering at a certain point in an individual or organization's development.

The decision-making process, particularly to enter the Greencorps program, was critical for empowerment outcomes. On Halsted, this process was fairly inclusive, while on Ashland and Pulaski it was not. This reflects the degree to which local organizers were empowering (Zimmerman 2000). All of the organizers were empowered: They knew who to contact to meet individual and community needs; they took action to improve their lives. But two of these local organizers were not empowering-those on Ashland and Pulaski. At Jefferson Homes and Halsted, local organizers were better able to draw on their neighbors' strengths and foster growth and productive involvement in the local area. Empowering local organizers make for empowering projects.

The Jefferson Homes and Pulaski experiences suggest an important aspect to social benefits from urban greening projects. Different types of projects may be empowering for an individual or group at different points in their development. The residents at Pulaski had yet to coordinate a successful block party, while at Jefferson Homes, a core group of resident organizers were about to take over management of the development. Pulaski residents might have needed an even more modest victory than that offered by a greening project while the Jefferson Homes organizers might have already gained the empowerment skills possible from such projects. The other greening projects implemented at Jefferson Homes provide further evidence of this. The sod and flower circle projects drew on existing empowerment among the core activists (e.g., ability to get in-kind resources). This empowerment had been gained from past projects, and these greening projects did not add to the individual or organizational empowerment of this group of residents. On Halsted, the timing was just right. The fight against the tavern had been successful, and the amount of organizing, outside contacts, and other empowerment aspects of a greening project were an appropriate next step in the Halsted block club's evolution as a force for positive neighborhood change.

One way that the residents on Halsted might have been more productive was if Greencorps was networked with other neighborhood assistance programs. Such a network would provide further resources to any group that enters any community development program in the network. Greening programs can network themselves among school advocacy groups, public health groups, recreation groups, job training programs, and myriad other social programs that exist in communities large and small. Facilitating the next possible steps for groups interested in continuing to improve their blocks and neighborhoods would foster empowerment. This network would create more ties between neighborhood-level groups and regional groups, which in turn could strengthen the community (Warren 1988).

\section{PUTTING EMPOWERMENT INTO PRACTICE: RECOMMENDATIONS FOR URBAN AND COMMUNITY FORESTERS}

Social benefits from urban and community forestry and related greening programs are a possible, but not automatic, outcome of these projects. Practitioners interested in these benefits can structure their programs in ways to foster some of these outcomes. There are several issues and recommendations to consider before, during, and after an urban and community forestry project intended to result in social benefits.

Before the project:

- What benefits and goals do the local residents identify as important (McDonough et al. 1994)? Obtaining this information will require listening and analysis by the practitioner. No one will say "we need to plant more trees to reduce stress and raise our cognitive functioning." But they might say "This place brings you down. We need more life here, more color!" In this case, a landscape project on the block could have a significant impact.

- Do the needed benefits stem from a green landscape or active involvement in a greening project or both?

- Are the needs of a target population for benefits at the individual, organizational, or community level, or some combination?

- Local resident motivations may be different depending on whether they are concerned most about their neighborhood or the environment. The outreach should be structured accordingly. 
- Empowerment is a developmental process. Gains from active involvement in greening projects can be very helpful at a certain point in this development, but too early or too late and the empowerment benefits might not be realized. For example, the core group of active residents at Jefferson Homes was beyond gaining empowerment from a modest greening project. What evidence is there of the local residents' level of empowerment?

During the project:

- Process is key. Foster open and inclusive decision making in greening projects. Not all greening practitioners are experienced in organizing. There are other organizations in most communities that do focus on organizing and community development. Partnering with these organizations may be helpful for greening practitioners who are not sure of how to facilitate an inclusive process.

- Watch out for empowered but not empowering local participants, particularly those who dominate a project. Greening practitioners may be able to foster a more empowering process for a project or intervene in other ways to strengthen empowerment outcomes in the face of a more domineering local participant. Intervention on Pulaski or Ashland might have helped the empowered local organizers become more empowering as well, with more positive repercussions for the block and neighborhood.

After the project:

- Practitioners should take their assessments of the impacts on a neighborhood with a grain of salt, recognizing that they might not see all the important interactions among project participants and nonparticipants. A successful tree planting project does not necessarily indicate success in generating social benefits, as is clear in the experience on Ashland where the garden thrived but there were some negative social impacts from the project.

- Networking with other good, nongreening organizations (e.g., education, job creation, and sports organizations) can further the empowerment potential from greening projects. This network can help a greening practitioner gain rapport and access to groups and neighborhoods they are unfamiliar with. More importantly, these other nonprofit groups or agency programs can bring further resources to the neighborhood and can create additional ties between local individuals and organizations and the wider community. Other organizations can also provide programs or projects that are the next step for a neighborhood-either a simpler project or a more complex one, depending on the neighborhood skills and interest. In this way, a network of greening groups and other organizations can match the empowerment level of a neighborhood and continue the empowerment process through multiple projects and programs. This kind of network might have fostered additional empowerment on Halsted, helping residents to take the next steps in "bringing the block up" and on Pulaski, helping residents take the first, smaller steps needed toward empowerment.

- Whether empowerment outcomes from active involvement come to fruition or not, greening projects may also confer or enhance benefits from living in a green environment. This is also one way that individual- or group-level benefits can have an impact at the community level. Ongoing maintenance of a greening project and the level of existing green landscape will have an impact on the benefits possible from the changes produced by these projects.

- Recognize that urban and community forestry is a part of the solution but cannot transform a distressed neighborhood alone.

Urban and community forestry plays a key role in enhancing quality of life. This role can be furthered by careful thought and planning regarding the myriad potential social benefits available through urban and community greening programs. Through enhanced experiences of green landscapes and programs fostering active involvement in urban greening, urban and community foresters can be a very real part of the solution to difficult social issues faced by communities large and small.

\section{LITERATURE CITED}

Amacher, R.C., and H.H. Ulbrich. 1986. Principles of Economics. South-Western Publishing Co., Cincinnati, OH. 913 pp.

Bouza, A.V. 1989. Trees and crime prevention, pp 31-32. In Rodbell, P.D. (Ed.). Proceedings of the Fourth Urban Forestry Conference: Making Our Cities Safe for Trees. American Forests, Washington, DC.

Cackowski, J.M. 1999. The Restorative Effects of Nature: Implications for Driver Anger and Frustration. Master's Thesis. The Ohio State University, Columbus, $\mathrm{OH}$.

Chenoweth, R. 1984. Visitor employed photography: A potential tool for landscape architecture. Landscape J. 3(2): 136-150.

Collier, J., and M. Collier. 1986. Visual Anthropology. University of New Mexico Press, Albuquerque, NM. 248 pp.

Dey, I. 1993. Qualitative Data Analysis: A User-Friendly Guide for Social Scientists. Routledge, London, UK. 285 pp.

Evans, L. 1994. Empowering people: Local and regional urban forestry organizations, pp 248-249. In Kollin, C., J. Mahon, and L. Frame (Eds.). Proceedings of the Sixth 
National Urban Forest Conference. American Forests, Washington, DC.

Feldman, R.M., and S. Stall. 1994. The politics of space appropriation: A case study of women's struggles for homeplace in Chicago public housing, pp 167-199. In Altman, I., and A. Churchman (Eds.). Women and the Environment. Plenum Press, New York, NY.

Fried, M. 1982. Residential attachment: Sources of residential and community satisfaction. J. Soc. Issues 38(3):107-119.

Kaplan, R. 1993a. The role of nature in the context of the workplace. Landscape Urban Plann. 26:193-201.

- 1993b. Urban forestry and the workplace, pp 4145. In Gobster, P.H. (Ed.). Managing Urban and High-Use Recreation Settings: Selected Papers from the Urban Forestry and Ethnic Minorities and the Environment Paper Sessions, International Symposium on Society and Natural Resources. USDA Forest Service, St Paul, MN.

- 2001. The nature of the view from home. Environ. Behav. 33(4):507-542.

Kollin, C. 1986. Citizen action and the greening of San Francisco, pp 96-99. In Phillips, A.F, and D. J. Gangloff (Eds.). Proceedings of the Third National Urban Forestry Conference. American Forests, Washington, DC.

Kuo, F. 2003. The role of arboriculture in a healthy social ecology. J. Arboric. 29(3):148-155.

Kuo, F.E., M. Bacaicoa, and W.C. Sullivan. 1998. Transforming inner-city landscapes: Trees, sense of safety, and preference. Environ. Behav. 30(1):28-59.

Kuo, F.E., and W.C. Sullivan. 1996. Do Trees Strengthen Urban Communities, Reduce Domestic Violence? USDA Forest Service Southern Region, Athens, GA.

-2001. Environment and crime in the inner city: Does vegetation reduce crime? Environ. Behav. 33(3):343-365.

Lofland, J., and L.H. Lofland. 1995. Analyzing Social Settings. Wadsworth Publishing Co., Belmont, CA. 268 pp.

Lyons, J.R. 1986. Congress and urban forestry, pp 264-266. In Phillips, A.F., and D.J. Gangloff (Eds.). Proceedings of the Third National Urban Forestry Conference. American Forests, Washington, DC.

McDonough, M.H., K.E. Vatcha, S.L. Funkhouser, and A.L. Gieche. 1994. Creating Community-Forestry Partnerships: A Participatory Approach. Department of Forestry, Michigan State University, East Lansing, MI.

Miles, M.B., and A.M. Huberman. 1994. Qualitative Data Analysis: An Expanded Sourcebook. Sage Publications, Thousand Oaks, CA. 338 pp.

Parsons, R., L.G. Tassinary, R.S. Ulrich, M.R. Hebl, and M. Grossman-Alexander. 1998. The view from the road: Implications for stress recovery and immunization. J. Environ. Psychol. 18(2):113-140.

Patel, I.C. 1992. Socio-economic impact of community gardening in an urban setting, pp 84-87. In Relph, D. (Ed.). The Role of Horticulture in Social Well Being. Timber Press, Portland, OR.

Pauline, R. 1993. Greening, neighborhood pride and sense of place, pp 125. In Kollin, C. (Ed.). Proceedings of the Sixth National Urban Forest Conference. American Forests, Washington, DC.

Perkins, D.D., and M.A. Zimmerman. 1995. Empowerment theory: Research and application. Am. J. Community Psychol. 25(5):569-580.

Phillips, S.B., and J. Garcia. 1994. The Pennsylvania Horticultural Society's Philadelphia Green, pp 154-156. Proceedings of the Sixth National Urban Forest Conference. American Forests, Washington, DC.

Qualitative Solutions and Research. 1997. QSR NUD*IST Qualitative Analysis Software. Qualitative Solutions and Research, Melbourne, Australia.

Rappaport, J. 1981. In praise of paradox: A social policy of empowerment over prevention. Am. J. Community Psychol. 9(1):1-25.

- 1987. Terms of empowerment/exemplars of prevention: Toward a theory for community psychology. Am. J. Community Psychol. 15(2):121-148.

Taylor, A.F, F.E. Kuo, and W.C. Sullivan. 2001. Coping with ADD: The surprising connection to green play settings. Environ. Behav. 33(1):54-77.

Taylor, A.F, A. Wiley, F.E. Kuo, and W.C. Sullivan. 1998. Growing up in the inner city: Green spaces as places to grow. Environ. Behav. 30(1):3-27.

U.S. Kerner Commission. 1968. Report of the National Advisory Commission on Civil Disorders. The National Advisory Commission on Civil Disorders, Washington, DC. 425 pp.

Ulrich, R.S. 1984. View through a window may influence recovery from surgery. Science 224(27 April 1984):420_ 421.

USDA Forest Service. No date. Empowering a Community: The USDA Forest Service's Role in Rebuilding Los Angeles. USDA Forest Service, no city listed.

Warren, R.L. 1988. The Community in America, pp 152157. In Warren, R.L., and L. Lyon (Eds.). New Perspectives on the American Community. Wadsworth Publishing Co., Belmont, CA.

Weick, K.E. 1984. Small wins: Redefining the scale of social problems. Am. Psychol. 39(1):40-49.

Wells, N.M. 2000. At home with nature: Effects of "greenness" on children's cognitive functioning. Environ. Behav. 32(6): 775-795.

Westphal, L.M. 1993. Why trees? Urban forestry volunteers values and motivations, pp 19-23. In Gobster, P.H. (Ed.). Managing Urban and High Use Recreation Settings: Selected Papers from the Urban Forestry and Ethnic Minorities and the Environment Paper Sessions, 
International Symposium on Society and Natural Resources. USDA Forest Service, St Paul, MN.

_ 1995. Participation in urban forestry projects: How the community benefits, pp 101-104. In Kollin, C., and M. Barratt (Eds.). Proceedings of the 7th National Urban Forest Conference. American Forests, Washington, DC. . 1999. Growing Power: Social Benefits of Urban Greening Projects. Doctoral Dissertation. University of Illinois at Chicago, Chicago, IL.

. 2000. Increasing the trustworthiness of research results: The role of computers in qualitative text analysis, pp 1-6. In Bengston, D. (Ed.). Applications of Computer Text Analysis in Natural Resources. USDA Forest Service, St. Paul, MN.

Wolf, K. 2003. Public response to the urban forest inner-city business districts. J. Arboric. 29(3): 117-126.

Zimmerman, M.A. 1995. Psychological empowerment: Issues and illustrations. Am. J. Community Psychol. 25(5):581-599.

- 2000. Empowerment theory: Psychological, organizational, and community levels of analysis, pp 4363. In Rappaport, J., and E. Seidman (Eds.). Handbook of Community Psychology. Kluwer Academic/Plenum Press, New York, NY.

Zimmerman, M.A., B.A. Israel, A. Schulz, and B. Checkoway. 1992. Further explorations of empowerment theory: An empirical analysis of psychological empowerment. Am. J. Community Psychol. 20(6):707-727.

Zimmerman, M.A., and S. Warschausky. 1998. Empowerment theory for rehabilitation research: Conceptual and methodological issues. Rehabil. Psychol. 43(1):3-16.

\section{Research Social Scientist}

USDA Forest Service

North Central Research Station

1033 University Place, Suite 360

Evanston, IL 60201-3172, U.S.

lwestphal@fs.fed.us

Résumé. Cet article fournit un cadre pour évaluer les bénéfices sociaux des projets de foresterie urbaine. $\mathrm{Ce}$ cadre clarifie qui retire les bénéfices: un individu?, une organisation?, une communauté? De plus, les bénéfices peuvent être dérivés de l'expérience passive et/ou active de la forêt urbaine. Des exemples de bénéfices sociaux dans chaque catégorie sont revus. Cet article présente aussi des découvertes à partir d'un projet de recherche à propos des revendications de bénéfices sociaux obtenus à partir de projets de reverdissement en milieu urbain. Les évaluations des praticiens quant aux bénéfices ont reçu un support modeste à partir des résultats de cette recherche, mais par contre leurs évaluations n'étaient pas entièrement précises, laissant par là certaines revendications fausses et d'autres vraies à propos des bénéfices sociaux. La théorie de la capacité de la pleine autorité a structuré l'enquête et l'analyse, et a fourni des idées pour l'implantation de projets qui visent à obtenir des bénéfices sociaux. Le concept de déléguer la pleine autorité aux gens versus celui des gens qui s'emparent de la pleine autorité a été particulièrement utile. Plus particulièrement, l'autorité naturelle de chaque organisateur de projet sur le terrain, l'ouverture d'esprit au sein du processus du projet, ainsi que l'organisation historique du quartier sont importants pour atteindre une situation de pleine autorité. Larticle conclut sur des recommandations pour les praticiens intéressés à encourager une situation de pleine autorité dans les projets de foresterie urbaine et communautaire.

Zusammenfassung. Dieser Bericht liefert einen Rahmen, in welchem soziale Vorteile in urbanen und kommunalen Forstprojekten zu überlegen sind. Der Rahmen klärt, wer die Vorteile geniesst:. ein Individuum, eine Organisation, eine Kommune. Desweiteren können die Vorteile entstehen aus passiven und/oder aktiven Erfahrungen aus der Forstwirtschaft. In jeder Kategorie werden Beispiele sozialer Vorzüge beleuchtet. Der Bericht zeigt auch Ergebnisse von Forschungsprojekten, die die Bedürfnisse von Praktikern bei sozialen Vorteilen urbaner Begrünungsprojekten zum Thema hatten. Die Befragung von Praktikern zu den sozialen Vorteilen fand große Unterstützung, aber die Befragung waren nicht akurat und führten damit zu einigen falschen und einigen richtigen Ansprüchen an soziale Vorteile. Die Konzepte der Bevollmächtigung versus befugter Personen war besonders hilfreich. Besonders die bekräftigende Natur der Projekt- und Standortplaner, die Offenheit für den Projektprozeß und die ganze Organisationsgeschichte des Blocks waren wichtig, um die angestrebten Ziele zu erreichen. Der bericht schließt mit Empfehlungen für interessierte Praktiker in der Unterstützung von Bevollmächtigungen durch urbane und kommunale Forstprojekte.

Resumen. Este reporte proporciona un esquema de trabajo con el cual se puedan considerar los beneficios sociales de los proyectos forestales urbanos y comunitarios. El esquema clarifica quién obtiene los beneficios - ¿Un individuo? Una organización? ¿Una comunidad? Por consiguiente, los beneficios pueden derivarse de la experiencia activa y/o pasiva del bosque urbano. Se revisan ejemplos de los beneficios sociales en cada categoría. El reporte también presenta los logros de proyectos de investigación que indagaron reclamos por beneficios sociales de los proyectos de enverdecimiento urbano. Las evaluaciones de los beneficios recibidos no fueron enteramente precisas. La teoría estructuró la investigación y análisis, y proporcionó ayuda importante. 